\title{
Legitimasi Berlapis dan Negosiasi Dinamis pada Pembayaran Perkawinan Perspektif Pluralisme Hukum
}

\author{
Atun Wardatun \\ Fakultas Syariah Universitas Islam Negeri Mataran \\ e-mail: atun_wardatun@uinmataram.ac.id
}

\begin{abstract}
This article is based on an ethnographic study that uses participatory observation of eight marriage payment negotiations in the city of Mataram, West Nustaenggara. It argues that the marriage payment in the Muslim tradition of Sasak in the city of Mataram is based on strong legal pluralism or a variety of equally strong laws in which no single legal system dominates and is subordinated to each other. Furthermore, this research sheds light on extending meaning of legal pluralism in which it may include dialogue between the same legal system eg between different customary laws. This strong model of legal pluralism is seen in two ways. First, the layered legitimacy of Sasak marriage by using many models of marriage payments, namely religious payment in the form of mahr for marriage validity, local payment in the form of pisuke and ajikrama for social appropriateness, and state payment in the form of administrative costs for formal legality. Second, the dynamic negotiation between customary law holders concerning the marriage payment when inter-ethnicity marriage occurs (exogamy), where different traditions can absorb each other. The argument at the same time debates the view that has placed the three legal systems: Islam, adat (customs), and the state as opposed and subordinate to each other.
\end{abstract}

[

Artikel ini berdasarkan penelitian etnografi dengan metode observasi partisipatif terhadap delapan negosiasi pembayaran perkawinan di Kota Mataram NTB. Argumen yang disampaikan adalah pembayaran pernikahan dalam tradisi Muslim Sasak di Kota Mataram NTB dilandasi oleh strong legal pluralism atau beragamnya hukum yang samasama kuat, tidak ada satu sistem hukum yang mendominasi dan tersubordinasi satu sama lain. Bahkan pluralisme hukum bisa mencakup dialog antara sistem hukum yang sama misalnya antara hukum adat yang berbeda. Model pluralisme hukum yang kuat tersebut terlihat pada dua hal. Pertama, legitimasi berlapis bagi perkawinan masyarakat Sasak dengan menggunakan banyak model pembayaran perkawinan yaitu pembayaran agama dalam bentuk mahar untuk sahnya pernikahan, adat dalam bentuk pisuke dan ajikrama untuk kepatutan sosial, dan negara dalam bentuk biaya administrasi untuk legalitas formal. Kedua, negosiasi yang dinamis antara pemegang hukum adat terkait pembayaran pernikahan ketika terjadi perkawinan antar suku (eksogami), di mana tradisi yang berbeda bisa menyerap satu sama lain. Argumen tersebut sekaligus mendebat pandangan selama ini yang meletakkan ketiga sistem hukum: Islam, adat, dan negara sebagai saling berlawanan dan mensubordinasi satu sama lain.

Keywords: pluralisme hukum; pembayaran perkawinan; adat; mahar; legitimasi 
Atun Wardatun

\section{Pendahuluan}

Islam, adat, dan negara adalah tiga aspek yang sangat berkaitan di dalam diskusi hukum keluarga Islam, termasuk hukum perkawinan. Masing-masing mereka berkontribusi bagi pembentukannya. Sayangnya, ketiga aspek ini sering diposisikan berhadap-hadapan sehingga terkesan berlawanan dan saling menegasikan. Ada banyak aspek dalam hukum keluarga di mana hukum Islam yang direpresentasikan oleh fiqh menjadi senjata untuk menyalahkan praktek-praktek yang lama telah terjadi di masyarakat (adat). Sering misalnya berkembang pendapat yang menyamakan model-model pembayaran perkawinan yang diakui secara adat dengan mahar ${ }^{1}$ misalnya sompa bagi etnis Bugis di Sulawesi Selatan, ${ }^{2}$ jujuran bagi masyarakat Banjar di Kalimantan Selatan, co'í bagi masyarakat Bima, dan pisuke bagi masyarakat Sasak di Nusa Tenggara Barat. Bahkan adapula yang menganggap eksistensi pembayaranpembayaran tersebut kurang penting dan bertentangan dengan hukum Islam sembari menggarisbawahi hanya mahar yang diakui oleh Islam dan menentukan keabsahan. ${ }^{3}$

Kontestasi hukum Islam dan hukum adat ini semakin runyam karena dalam konteks negara muncul juga hukum nasional yang berpretensi mengklaim diri sebagai satu-satunya hukum yang legitimate. Hukum negara terkadang berlawanan dengan tradisi yang telah diikuti secara turun temurun, misalnya terlihat dalam aturan tentang pembayaran perkawinan yang di dalam Kompilasi Hukum Islam (KHI) 1/19914 disederhanakan dengan mengambil hukum Islam saja tanpa memberikan ruang justifikasi bagi hukum adat.

\footnotetext{
${ }^{1}$ Noryamin Aini, "Tradisi Mahar di Ranah Lokalitas Umat Islam: Mahar dan Struktur Sosial di Masyarakat Muslim Indonesia," Ahkam: Jurnal Ilmu Syariah 14, no. 1 (2014), https://doi.org/ 10.15408/ajis.v17i1.1239; Aris Nur Qadar Ar-Razak, "Praktek Mahar Dalam Perkawinan Adat Muna (Studi Kabupaten Muna, Sulawesi Tenggara)" (Tesis, Universitas Islam Negeri Sunan Kalijaga, 2015).

${ }^{2}$ Sri Rahayu and Yudi Yudi, “Uang Nai': Antara Cinta dan Gengsi," Jurnal Akuntansi Multiparadigma 6, no. 2 (2015): 224-36, https://doi.org/10.18202/jamal.2015.08.6018.

${ }^{3}$ Hirmayadi Saputra, "Hukum Adat dan Hukum Islam dalam Tradisi Penentuan Mahar di Kecamatan Pujut Kabupaten Lombok Tengah," Tafaqquh: Jurnal Hukum Ekonomi Syariah dan Ahwal Syahsiyah 1, no. 2 (2016): 76-86, http://ejournal.kopertais4.or.id/sasambo/index.php/ tafaqquh/ article/view/3048; Lalu Yoga Vandita, "Praktek Tradisi Gantiran dalam Perkawinan Persfektif Hukum Islam," Tafaqquh:Jurnal Hukum Ekonomi Syariah dan Ahwal Syahsiyah 1, no. 1 (2016): 58-72, http://ejournal.kopertais4.orid/sasambo/index.php/tafaqquh/article/view/3038.

${ }^{4}$ Dalam Kompilasi Hukum Islam, perkara mahar disebutkan pada buku I bab V pasal 30-38.
} 
Dalam hal ini KHI hanya menyebut tentang mahar dengan tidak menyertakan atau mengindikasikan ada pembayaran lain yang diakui oleh adat. Padahal dalam prakteknya, hukum adat justru lebih menyita perhatian dan memerlukan negosiasi yang lebih alot ketimbang hukum Islam walaupun menurut asumsi saya keduanya masih dipandang memiliki signifikansi yang sama. Hal ini membuktikan bahwa KHI sebagai representasi aturan yang dikeluarkan oleh negara masih luput mengatur pertautan adat dan Islam pada banyak materi hukum keluarga Islam.

Dialog antara Islam dan adat dalam praktek keagamaan Muslim Indonesia sendiri telah lama menarik perhatian para pakar hukum. Banyak teori yang berusaha memformulasikan bagaimana berlakunya hukum Islam dan interaksinya dengan adat lokal di Indonesia. Hanya saja teori-teori tersebut, sebagaimana yang akan dikemukakan di bawah ini, belum secara tuntas dan utuh menjelaskan variasi praktek keislaman pada masyarakat Indonesia yang sangat plural. Hal ini tentu menarik dan menjadi pendorong bagi upaya melakukan kajian yang terus menerus tentang interaksi adat dan Islam di berbagai masyarakat Muslim di Indonesia.

Berbagai teori tentang pemberlakuan hukum Islam dimaksud muncul sebagai tesis dan antitesis. Pada zaman penjajahan Belanda, muncul teori Receptio in Complexu yang dipopulerkan oleh van den Berg (1845-1925) yang mengatakan bahwa Islam berlaku secara menyeluruh dalam praktek kehidupan masyarakat Muslim Indonesia. Teori ini kemudian dilawan oleh Snouck Hurgrounje (1874-1933) dengan teori Receptie yang mengatakan bahwa Islam baru bisa berlaku jika diterima oleh adat lokal. Perdebatan kedua teori yang dikemukakan oleh sarjana Belanda tersebut dinilai oleh pakar hukum Indonesia tidak terlalu tepat. Hazairin bahkan menilai teori Receptie sebagai teori yang semata-mata dihajatkan untuk strategi politik penjajahan Belanda yang ingin menjauhkan masyarakat Muslim Indonesia dari hukum Islam. Oleh karenanya ia mengemukakan teori Receptie Exit yang berarti harus keluar dan tidak boleh menerima teori Receptie dengan berlakunya UUD 1945. 'Teori Receptie Exit ini belakangan disempurnakan oleh Sayuti Talib ${ }^{6}$ dengan teori Receptio a Contrario yang sangat bertolak belakang dengan teori Receptie.

${ }^{5}$ Hazairin, Tujuh Serangkai tentang Hukum (Jakarta: Tinta Mas, 1974).

${ }^{6}$ Sayuti Thalib, Receptio A Contrario (Jakarta: Bina Aksara, 1980). 
Menurut Sayuti Talib, justru hukum adat baru berlaku jika diterima oleh hukum Islam. ${ }^{7}$

Perdebatan hangat tentang hubungan Islam dan adat ini belum berhenti sampai di situ. Belakangan MB Hooker, Indonesianist dari Australia, memberikan cara pandang yang berbeda. Menurut dia, hukum adat dan hukum Islam tidak pada hubungan meresepsi satu sama lain karena hal itu terkesan saling menyisihkan. Daya ikat mereka sejajar dan masyarakat dengan kesadaran hukum masing-masinglah yang akan memilih mana sebenamya hukum yang ingin diberlakukan bagi mereka. Teori ini bernama teori sinkretisme yang melihat hubungan yang sejajar antara adat dan Islam dalam praktik keagamaan masyarakat Indonesia. Teori ini menerima dengan baik adanya pluralisme hukum dalam suatu masyarakat di mana terjadi keberadaan yang seimbang (co-existence) beberapa sistem hukum dan bersifat saling akomodatif. ${ }^{8}$

Dalam sistem pembayaran perkawinan, ada fenomena yang menarik yang bisa ditemukan pada beberapa masyarakat Muslim Indonesia. Masyarakat Muslim di beberapa wilayah di Indonesia memiliki komponen yang beragam dalam pembayaran perkawinan ini yang oleh beberapa peneliti dipilah menjadi mahar Islam dan mahar adat.9 Misalnya, masyarakat bilateral Banjar Kalimantan Selatan mempraktek jujuran, ada belis di masyarakat patrilineal di Nusa Tenggara Timur seperti di Ende dan Ruteng, uang japuik di masyarakat matrilineal Padang dan panai di masyarakat bilateral Tolaki di Kendari di luar mahar yang diakui Islam.

Praktek pembayaran perkawinan pada masyarakat Sasak Lombok menunjukkan adanya upaya dialog dan legitimasi hukum yang berbeda dengan teori hubungan antara hukum Islam dan hukum adat atau negara yang ada. Beragam prakek pembayaran yang terjadi merujuk pada jalinan dan tali temail diantara hukum islam, adat, dan aturan negara. Ketiganya berpacu memberi

${ }^{7}$ Ahmad Khumaidi Ja'far, "Teori-teori Pemberlakuan Hukum Islam di Indonesia," Asas 4, no. 2 (2012): 102-10, http://ejournal.radenintan.ac.id/index.php/asas/article/view/1679; Yaswiraman, Hukum Keluarga: Karakteristik dan Prospek Doktrin Islam dan Adat dalam Masyarakat Matrilineal Minangkabau (Jakarta: Raja Grafindo Persada, 2013); Fatah Hidayat, "Dinamika Perkembangan Hukum Keluarga di Indonesia," An Nisa'a 9, no. 2 (2014): 1-22, http://jurnal.radenfatah.acid/ index.php/annisa/article/view/265.

8M. B. Hooker, Islamic Law in South-East Asia (Singapore: Oxford University Press, 1984).

${ }^{9}$ Atun Wardatun, "Marriage Payment, Social Change, and Women 's Agency among Bimanese Muslims of Eastern Indonesia" (Tesis, Western Sydney University, 2016). 
pengaruh dan menunjukkan eksistensi dirinya. Tulisan ini berupaya menguak lebih dalam apa yang terjadi di masyarakat Muslim Sasak Lombok dalam praktek pembayaran perkawinan sebagai perwujudan legitimasi berlapis dan negoisasi tanpa antara kutub peraturan yang berbeda asal dan sumbernya.

\section{Kota Mataram, Suku Sasak, dan Tradisi Perkawinan}

Mataram adalah satu-satunya kota yang berada di pulau Lombok dari dua kota di Provinsi NTB selain delapan kabupaten lainnya. Satu kota lainnya berada di Pulau Sumbawa, yaitu Kota Bima. Kota Mataram sebelumnya menjadi bagian dari Lombok Barat dan sejak tahun 1978 terpisah menjadi Kota Administratif Mataram yang lalu pada tahun 1993 menjadi Kota Madya Mataram yang terkenal dengan sebutan kota Mataram saja. ${ }^{10}$ Sejak itu Mataram tumbuh berkembang menjadi wilayah yang paling urban di NTB. Di sini pulalah ibu kota Provinsi NTB terletak.

Kota Mataram berbatasan dengan Kecamatan Gunung Sari Kabupaten Lombok Barat di Utara, Kecamatan Labu Api Kabupaten Lombok Barat di Selatan, Selat Lombok di sebelah Barat dan Kecamatan Narmada, Kabupaten Lombok Barat di bagian timur. Luas daratan Kota Mataram adalah 61,30 km sedangkan lautnya seluas $56,80 \mathrm{~km}$. Secara administratif kota ini terdiri dari enam kecamatan, yaitu Kecamatan Ampenan, Cakranegara, Mataram, Sandubaya, Selaparang dan Sekarbela. Enam kecamatan tersebut terbagi lagi menjadi 50 kelurahan dan 297 lingkungan. Penelitian ini hanya meliput empat kecamatan yaitu kecamatan Ampenan, Cakranegara, Selaparang, dan Sekarbela. Dalam rentang waktu tiga bulan penelitian lapangan, kecamatan Mataram dan Sandubaya tidak tercover karena peneliti tidak berhasil menemukan peristiwa pernikahan dan negosiasi pembayaran yang bisa dijadikan situs penelitian. Hal ini terjadi karena beberapa faktor: jarak, kurang banyak penduduk asli, tidak ada gate keeper pada dua wilayah tersebut.

Perkembangan kota ini cukup melesat. Seiring dengan dicanangkannya NTB sebagai destinasi wisata halal terbaik di dunia, kota ini juga ikut mempersiapkan diri sebagai tuan rumah yang baik. Hotel-hotel tumbuh menjulang. Gerak ekonomi msayarakat juga melaju, terlihat indikatornya dengan munculnya pusat belanja atau mall yang lebih besar dibandingkan dengan mall Mataram yang

10“Sejarah Kota Mataram," http://www.mataramkota.go.id/sejarah. 
sudah puluhan tahun lebih berdiri. Di samping itu ruko-ruko telah terbangun memenuhi jalan-jalan utama. Sehingga hampir di semua depan jalan besar, sangat jarang ditemukan rumah kediaman, berganti dengan pusat-pusat usaha baik berbentuk ruko maupun kedai dan warung. Supermarket seperti Giant dan Hypermart maupun gerai minimarket seperti Alfamart dan Indomart juga tumbuh dan berkembang demikian cepat. Fasilitas untuk masyarakat urban yang tengah berkembang menuju masyarakat metropolis di Kota Mataram juga terus dipacu. Jalan-jalan baru sudah terbuka untuk lebih memudahkan akses dan mobilisasi masyarakat baik kepada tempat kerja, lembaga pendidikan, maupun kebutuhan-kebutuhan lainnya.

Kehidupan beragama pun tidak kalah semarak. Kota Mataram yang merupakan bagian dari pulau Seribu Masjid ini memiliki banyak sekali bangunan masjid yang arsitekturnya indah dan megah. Dalam sebuah kampung, masjid bisa berdiri berhadap-hadapan hanya dipisahkan oleh sebuah gang. Sekarang di kota ini telah juga berdiri megah Islamic Centre yang juga berfungsi sebagai icon religiusitas masyarakat Muslim di NTB.

Penduduk asli kota ini adalah Suku Sasak yang juga merupakan suku mayoritas penghuni Kota Mataram. Suku lain juga penghuni kota ini baik yang berasal dari pulau Sumbawa yang merupakan wilayah Provinsi NTB yaitu Suku Mbojo, Samawa mapun yang dari luar yaitu Suku Bali, Tionghoa, Melayu dan Arab. Masing-masing suku ini menggunakan bahasa mereka masingmasing dalam relasi internal yaitu Bahasa Sasak, Mbojo, Samawa, Jawa dan lain-lain. Bahasa Indonesia menjadi bahasa pemersatu dan merupakan bahasa resmi di lembaga pemerintahan dan pendidikan.

Suku Sasak memiliki sistem kekerabatan bilateral dalam arti keturunan diakui baik dari jalur ibu maupun bapak. Dalam masalah tertentu seperti warisan, sistem kekerabatan cenderung bersifat patrilineal, anak laki-laki mewarisi harta sebagai hak milik sedangan anak perempuan hanya sebagai hak pakai. Sistem kediaman pun bersifat patrilokal, keluarga yang baru terbentuk cenderung tinggal di lingkungan suami dan ikut keluarga suami. Proses perkawinan sebagaimana yang akan dijelaskan di bawah ini pun dilakukan semuanya di tempat suami dan dana ditanggung sepenuhnya oleh pihak suami. ${ }^{11}$

\footnotetext{
11Jhon Ryan Bartholomew, Alif Lam Mim: Kearifan Masyarakat Sasak (Yogyakarta: Tiara Wacana, 2001); Erni Budiwanti, Islam Sasak: Wetu Telu versus Waktu Lima (Yogyakarta: LKiS, 2000).
} 
Berdasarkan Sensus Penduduk 2010, mayoritas penduduk Mataram beragama Islam sekitar $82.48 \%$. Penganut agama Hindu adalah yang terbesar kedua $13.99 \%$. Selain itu, penduduk kota juga menganut Kristen 1.67\%, Katolik, 0.75\%, Buddha 0.95\% dan Konghucu 0.01\%. Walaupun Islam merupakan agama mayoritas di Mataram, namun kerukunan umat beragama dengan saling menghormati, menghargai dan saling menolong untuk sesamanya adalah niat masyarakat Mataram dalam menjalankan amal ibadahnya, sesuai dengan visi kota Mataram untuk mewujudkan Kota Mataram maju, religius, dan berbudaya.

Masyarakat kota Mataram yang berasal dari Suku Sasak, baik yang asli dari daerah kota Mataram maupun dari tempat-tempat lain di pulau Lombok, masih mempertahankan tradisi pembayaran perkawinan yang umum dilakukan oleh masyarakat Sasak. Hal ini menarik ditelusuri lebih lanjut karena asumsinya struktur sosial masyarakat kota yang cenderung heterogen dan lebih terbuka memungkinkan perubahan tata nilai sosial lebih cepat yang juga membawa perubahan pada perilaku hukum, dalam hal ini hukum keluarga. Asumsi itu dipatahkan oleh hasil observasi penulis yang membuktikan bahwa dalam masalah pembayaran perkawinan, perubahan sosial masyarakat Kota Mataram tidak serta merta menghapus tradisi lokal, walaupun di sana sini memang ditemukan modifikasi dan penyesuaian.

\section{Prosesi Pernikahan Adat Suku Sasak}

Prosesi Pernikahan adat Suku Sasak berlangsung lama dan terdapat beragam ritual. Setidaknya penulis mengidentifikasi sebelas ritual yang dijalankan. Pertama, merariq atau melaik dan juga disebut memaling.12 prosesi pra perkawinan ini sangat unik karna calon mempelai perempuan dibawa ke

\footnotetext{
${ }_{12}$ Merariq berasal dari kata lari karena proses perkawinan ini dibawa lari, disebut juga melaik yang berarti sama. Memaling sebenarnya secara bahasa berarti berpaling muka. Hal ini diasosiasikan kepada orang tua para calon pengantin yang tidak mengetahui proses membawa lari ini. Dalam penggunaan sehari-hari banyak masyarakat yang mengartikan memaling ini dengan maling atau mencuri. Dalam aturannya, merariq ini memiliki persyaratan-persyaratan tertentu misalnya calon pengantin perempuan tidak dibawa ke rumah calon pengantin pria, proses membawa lari ini harus dilakukan pada malam hari selepas isya, ditemani oleh kawan yang lain agar tidak hanya mereka berdua yang keluar malam-malam, dan tidak boleh mengambil calon mempelai perempun selain dari rumah orang tuanya atau walinya. Akan tetapi di dalam praktiknya, aturan-aturan ini banyak dilanggar. Muhammad Harfin Zuhdi, "Praktik Merariq: Wajah Sosial Masyarakat Sasak" (Laporan penelitian, Lembaga Pengkajian-Publikasi Islam dan Masyarakat (LEPPIM) - IAIN Mataram, 2012).
} 
rumah tokoh adat atau tokoh masyarakat tanpa pemberitahuan terlebih dahulu kepada keluarga perempuan. Hal ini merupakan kesepakatan antara pria dan wanita yang sudah siap untuk berumah tangga.

Kedua, besejati: pemberian kabar yang dilakukan oleh aparatur desa yang juga disebut kliang dari tempat laki-laki terhadap kliang tempat tinggal perempuan, bahwa si perempuan telah dibawa lari oleh laki-laki yang merupakan penduduk desanya dan sekarang berada di desa wilayahnya. Hal ini biasanya dilakukan segera dan selambat-lambatnya satu atau dua hari setelah perempuan berada di tempat persembunyian yang mereka tuju, biasanya rumah kerabat laki-laki. Dalam kesempatan ini pula dibicarakan kapan kirakira keluarga calon pengantin perempuan menerima keluarga calon pengantin laki-laki.

Ketiga, nyelabar atau pemberian kabar. Pemberitahuan oleh kliang dan tokoh adat sebagai perwakilan keluarga laki-laki terhadap keluarga perempuan bahwasanya anak gadis mereka telah dibawa lari. Keempat, ngerunjung, merupakan proses dimana utusan laki-laki meminta atau menanyakan jumlah gantiran atau pisuke yang akan dibebankan terehadap keluarga laki-laki. Dalam praktek yang ditemukan oleh peneliti pada prosesi pernikahan di Kota Mataram, ngerunjung ini digabung dengan proses nyelabar dalam waktu yang bersamaan. Jadi pada proses nyelabar inilah dibicarakan tentang berbagai macam pembayaran yang akan dibebankan kepada pihak laki-laki. Terutama yang memerlukan negosiasi yaitu pisuke atau gantiran. Mengenai ajikrama yang juga merupakan pembayaran adat, kadarnya sudah ditentukan sesuai dengan status kebangsawanan ataupun tingkat keimanan yang diukur dari praktik agama seseorang. Proses nyelabar inilah yang menjadi obyek utama observasi pada peneltian ini.

Kelima, nunas wali atau juga disebut bait wali yang bermakna meminta wali. Wali pihak perempuan akan bersedia menikahkan jika telah terjadi kesepakatan mengenai besarnya gantiran atau pisuke. Jika tidak, maka wali belum bersedia menikahkan yang artinya pernikahan bisa tertunda sampai ditemukan kesepakatan. Dalam hal ini terjadi tarik menarik antara pihak keluarga. Di satu sisi praktik nunas wali dengan syarat kesepakatan pisuke ini menunjukkan agensi keluarga perempuan sebagai penentu dari pelaksanaan pernikahan. Tetapi penelitian ini menemukan bahwa dalam sela waktu kesepakatan itu, pihak perempuan sangat terbuka untuk menegosiasikan dan 
menurunkan jumlah permintaan yang telah disebut sebelumnya sehingga menemukan win-win solution. Pernikahan sesama Suku Sasak lebih menunjukkan ketetapan hati pihak perempuan untuk bertahan sesuai dengan jumlah awal sedangkan pada pernikahan yang terjadi dengan suku lain, negosiasi berjalan lebih lancar karena tidak banyak membicarakan tentang pembayaran adat ala Suku Sasak, hanya pembayaran-pembayaran yang memang diperlukan untuk pesta pernikahan dengan menyesuaikan dengan pembayaran adat yang berlaku di daerah asal pengantin perempuan.

Keenam, nikah atau akad ijab qabul. Dalam Bahasa Sasak disebut juga begawe atau roah. Bila sudah ada kesepakatan antara kedua belah pihak terkait wali perempuan, maka proses nikah akan bisa dilaksanakan. Nikah yang dimaksud di sini adalah pelaksanaan aqad nikah di mana terjadi ijab qabul dan serah terima mahar dari pengantin laki-laki kepada wali pengantin perempuan yang lalu akan diteruskan kepada pengantin perempuan. Jika sebelumnya telah diserahkan pisuke, maka biasanya aqad nikah ini dibarengi dengan begawe atau roah (pesta dan syukuran pernikahan). Jika belum maka prosesnya masih berlanjut sebagaimana di bawah ini.

Ketujuh, bait janji, merupakan perundingan oleh keluarga laki-laki dan perempuan untuk menuntaskan rangkaian adat yang masih belum dilakukan seperti sorong serah dan menyerahkan gantiran/pisuke. Kedelapan, Nyerah gantiran/pisuke: proses dimana keluarga laki-laki menyerahkan gantiran yang sudah disepakati oleh kedua belah pihak. Dua langkah tersebut tidak selalu dilakukan setelah ijab qabul. Seringkali terjadi sebelum dilakukannya akad pernikahan. Seperti pada semua prosesi pernikahan yang saya amati, dua langkah ini telah dilakukan sebelum nikah. Alasannya, kalau dilakukan setelah nikah biasanya pihak perempuan meminta yang lebih tinggi dan sering digunakan untuk keperluan yang lain yang tidak berkait dengan pernikahan, misalnya untuk selamatan keluarga yang meninggal.

Kesembilan, sorong serah aji krama, proses sorong serah sama pentingnya dengan ijab qabul dalam aqad nikah. Proses ini merupakan inti dari segala rangkaian adat Sasak dan dianggap langkah yang melegitimasi ikatan pernikahan secara adat. Pembayaran dalam sorong serah ini berbentuk simbolis dengan memakai kepeng bolong (uang yang berlobang tengahnya) dan sudah tidak berlaku. Proses ini biasanya dilakukan sebelum proses nyongkolan (arakarakan) dan dipimpin oleh pembayun (perwakilan dari tokoh adat) masing- 
masing dari kedua belah pihak. Semua kerabat, saudara, dan keluarga masingmasing pihak hadir pada acara sorong serah ini.

Kesepuluh, nyongkol, adalah arak-arakan dengan membawa pengantin kerumah pengantin perempuan diikuti oleh masyarakat dan sanak kerabat. Proses ini menggambarkan kebahagiaan masyarakat menyambut keluarga baru dan sekaligus mengumumkan kepada khalayak akan terbentuknya ikatan pernikahan yang telah sah secara adat, agama, dan sosial. Proses nyongkolan ini diiringi dengan musik tradisional Sasak yaitu gendang beleq yang berarti gendang besar. Masyarakat mengiringi dengan nyanyian adat dan tari-tarian. Nyongkolan ini mutlak harus dilakukan setelah sorong serah karena iringiringan ini tidak diperkenankan masuk ke kediaman pengantin putri jika belum diselesaikan. Terakhir, kesebelas, bejango atau balas onos nae. Langkah ini kadang dilakukan tapi seringkali juga tidak. Inti dari tradisi ini adalah mempererat hubungan keluarga dekat kedua belah pihak dengan saling mengunjungi.

Hampir keseluruhan berhubungan dengan pembayaran pernikahan. Hanya langkah pertama, kedua dan terakhir yang tidak berhubungan dengan pembayaran pernikahan yaitu merariq, mesejati dan bejango. Sedangkan dari nyelabar sampai nyongkolan sangat erat kaitannya dengan variasi pembayaran pernikahan baik secara langsung maupun tidak langsung. Dalam prosesi nyelabar misalnya kedua belah pihak membicarakan tentang pisuke dan jika tidak terjadi kesepakatan maka proses selanjutnya tidak dapat diteruskan. Demikian pula pada nyongkol yang terancam tidak bisa dilakukan sebelum sorong serah dilaksanakan. Jadi pembicaraan dan signifikansi masing-masing langkah itu bisa dikatakan sangat bergantung pada kesepakatan tentang biaya dan pembayaran pernikahah. Akad ijab qabul juga tentu tidak bisa dilaksanakan jika pembayaran perkawinan dalam bentuk mahar belum disepakati. Karena pada langkah ini perlu disebutkan secara jelas bentuk dan jumah dari mahar tersebut. Demikian pentingnya pembayaran pernikahan ini dapat dilihat energi yang dihabiskan dalam setiap prosesi pernikahan dalam tradisi Sasak di atas.

\section{Pembayaran Perkawinan dan Legitimasi Berlapis}

Terdapat tiga jenis atau istilah pembayaran dalam prosesi perkawinan Suku Sasak Lombok, yaitu pembayaran agama, pembayaran adat, dan pem- 
bayaran adminitrasi. Pertama, pembayarana agama. Pembayaran agama merupakan pembayaran yang didasarkan pada perintah agama bagi masyarakat Sasak yang biasa disebut mahar. Mahar ini menjadi hak milik perempuan. Jumlah dan bentuknya memerlukan biaya yang lebih sedikit dibandingkan dengan pembayaran adat. Untuk menyepakati jumlah dan bentuk ini tidak memerluakan negosiasi yang panjang. dalam praktik yang dilakukan oleh informan penelitian ini, sebagian mereka menyepakati sendiri dan tinggal diperkuat oleh pertemuan keluarga sebagaian yang lain disepakati oleh pihak keluarga saja tanpa menanyakan kepada calon pengantin perempuan.

Kedua, pembayaran adat. Pembayaran jenis ini lebih bervariasi baik yang pasti dilakukan seperti gantiran dan pisuke serta aji krama atau karena kondisi tertentu seperti pelengkak dan pewirang. Semuanya didasarkan pada adat istiadat Suku Sasak. Khusus masalah gantiran dan pisuke, ada yang menyamakan ada pula masyarakat yang membedakan. Tetapi pada dasarnya kedua istilah ini sama yaitu merujuk kepada pembayaran adat yang dilakukan oleh pihak calon suami kepada keluarga calon istri dan tidak menjadi hak milik calon istri. Pembedaan istilah tersebut hanya merujuk pada arti yang keduaduanya dilalui pada negosiasi pembayaran ini.

Gantiran merupakan harta yang diberikan oleh keluarga laki-laki terhadap keluarga perempuan dan menjadi hak milik secara penuh. Sehingga kedua mempelai tidak memiliki hak sedikitpun terhadap harta tersebut, baik ketika keluarga itu masih utuh atau bercerai. Harta gantiran tidak boleh ditarik kembali secara keseluruhan kecuali terjadi perceraian dan belum berkumpul. Ketika orang yang menguasai harta gantiran itu meninggal, maka kedua mempelai tidak mendapatkan bagian dari harta itu, melainkan harus dibagi kepada ahli waris yang lain. ${ }^{13}$

Adapun aji krama adalah pembayaran secara simbolis yang didasarkan pada status sosial pengantin perempuan yang dilihat dari keturunannya apakah bangsawan atau tidak. Penyerahan ini dilakukan dalam upacara yang disebut sorong serah. Jadi inti dari sorong serah aji krama ini adalah legitimasi adat bagi terjadinya ikatan perkawinan. Tetapi menurut budayawan, sebenar-

\footnotetext{
13Lalu Yoga Vandita, "Praktek Tradisi Gantiran dalam Perkawinan Persfektif Hukum Islam," Tafaqquh: Jurnal Hukum Ekonomi Syariah dan Ahwal Syahsiyah 1, no. 1 (2016): 58-72, http://ejournal.kopertais4.or.id/sasambo/index.php/tafaqquh/article/view/3038.
} 
nya tingkatan keagamaan dan moralitas juga bisa dijadikan dasar tidak saja kebangsawanan. Tingkatan kehormatan ini diistilahkan dengan menak yang berarti mulia. Menariknya, harga kehormatan berdasarkan tingkat tersebut digantungkan kepada ibu dari mempelai perempuan.

Ada empat tingkatan menak. Menak tulen (utama), secara garis keturunan menunjukkan keluarga bangsawan, secara kepribadian adalah sosok yang konsisten terhadap nilai-nilai agama; berbudi, berakhlakul karimah. Pada strata ini harganya 99 disamakan dengan asmā' al-husnā. Menak madya, pribadi yang beragama, memegang adat tapi belum mencapai tingkat kualitas keimanan seperti menak utama di atas, harganya 66. Menak harga 33, pribadi yang beriman sudah melaksanakan shalat dengan baik, orang-orang kebanyakan dihargakan 33. Menak harga 17, sekedar Islam saja tetapi tidak konsisten dalam menjalankan syara', misalnya Islam tapi belum mampu menghafal al-Fatihah, kelompok ini dihargakan 17.14

Sedangkan dua jenis pembayaran lainnya yaitu pelengkak dan pewirang terjadi karena ada situasi tertentu. Pelengkak merujuk pada pembayaran yang dilakukan oleh seseorang yang melangkahi kakaknya dengan menikah duluan. Pembayaran ini dilakukan oleh sang adik yang menikah dan menjadi hak milik dari kakak yang dilangkahi. Sedangkan pewirang adalah pembayaran yang dilakukan oleh calon pengantin laki-laki sebagai pemenuhan janji yang pernah diucapakan ketika terjadi midang (proses perkenalan) dulu.

Ketiga, pembayaran administrasi. Pembayaran jenis ini tidak memerlukan negosiasi pihak-pihak yang terlibat karena jumlahnya biasanya telah disepakati baik pada aturan desa maupun Kantor Urusan Agama yang mengeluarkan surat nikah. Pada umumnya, pembayaran ini yang sering dikesampingkan oleh perkawinan adat Sasak karena dianggap tidak terlalu penting. Selain itu dikatakan seringkali ada pungutan berantai dari kepala dusun sampai ketua RT dan kepala lingkungan dan tidak diteruskan untuk mengurus surat pernikahan. Hanya saja pada delapan pernikahan sebagaimana yang disebut sebelumnya semua tetap membayar syarat-syarat administrasi ini.

${ }^{14}$ E. Suryani, "Merarik dalam Bingkai Kearifan Masyarakat Lombok," dalam Atun Wardatun, et al. Jejak Jender (Mataram: PSW IAIN Mataram, 2010). 


\section{Negosiasi dan Keterbukaan Budaya dalam Pluralisme Hukum}

Penulis berkesempatan mengamati delapan pasangan calon pengantin, empat pasang dilakukan sesama Suku Sasak dan empat lainnya antara Suku Sasak dengan suku lain: dua dengan Suku Mbojo, satu dengan Suku Banjar, dan satu lagi dengan suku Jawa. Di antara perkawinan antar suku tersebut, hanya satu yang perempuannya berasal dari Suku Sasak yaitu perkawinan dengan suku Jawa, selebihnya dilakukan antara laki-laki Suku Sasak dengan perempuan suku lain yaitu dari Suku Mbojo dan Suku Banjar.

Ada perbedaan yang mendasar antara perkawinan yang dilakukan antar Suku Sasak dengan antara suku yang lain yaitu pada penggunaan tradisi yang lebih kental baik terkait dengan bentuk perkawinan maupun sistem pembayaran dan tempat melaksanakan perkawinan. Pada perkawinan Suku Sasak, bentuk perkawinannya dilakukan dengan cara merariq (melarikan calon mempelai perempuan oleh mempelai laki-laki) sedangkan pada perkawinan dengan suku lain semuanya menggunakan sistem melamar, pengantin laki-laki meminta pengantin perempuan kepada keluarganya. Adapun sistem pembayarannya, pada perkawinan antar Suku Sasak, pisuke dan atau gantiran menjadi pembayaran adat selain mahar yang menentukan jadi atau tidaknya pernikahan, sedangkan pada perkawinan antar suku, lebih terfokus pada pembicaraan mengenai biaya pesta pernikahan.

Tempat perkawinan bagi pengantin Suku Sasak dilakukan di pihak lakilaki sedangkan antara Suku Sasak dengan suku lain dilakukan di tempat kediaman perempuan. Hanya perkawinan antara Suku Sasak dan Suku Banjar yang dilakukan di tempat kediaman pengantin laki-laki. Salah satu alasannya karena pengantin perempuan yang berasal dari Suku Banjar ini memiliki sedikit keluarga dan sanak saudara di sini sehingga kesibukan untuk menjadi tuan rumah tidak mungkin dilakukan.

Semua prosesi perkawinan di atas baik yang menggunakan cara melamar maupun merariq (perkawinan adat Suku Sasak) memiliki kesamaan bahwa pembayaran perkawinan yang dibebankan kepada pengantin laki-laki dan/atau keluarganya tidak hanya mahar atau sejumlah pembayaran yang diberikan oleh laki-laki sebagai hak milik perempuan, tetapi juga ada biayabiaya lain baik yang terkait dengan adat, administrasi, maupun biaya pesta pernikahan. Semua bentuk pembayaran itu dianggap sama pentingnya karena 
memiliki fungsi masing-masing. Hanya saja pembayaran selain mahar lebih memerlukan negosiasi yang alot dan terkadang berkepanjangan.

Khusus untuk perkawinan antara Suku Sasak, perbedaan pekerjaan, latar belakang pendidikan, status ekonomi dan wilayah tempat tinggal tidak terlalu memberikan pengaruh bagi variasi pembayaran perkawinan. Artinya mereka tetap membayar pisuke atau gantiran dan aji krama selain mahar. Akan tetapi perbedaan latar belakang tersebut mempengaruhi jumlah pembayaran maupun arti pembayaran perkawinan itu sendiri dan perbedaan tingkat kealotan negosiasi pembayaran perkawinan. Misalnya, di Kecamatan Sekarbela, negosiasi pembayaran adat berjalan lebih sederhana dan memakai asas cepat dan lancar dibandingkan dengan yang terjadi di tiga kecamatan lainnya.

Pada perkawinan sesama Sasak, bentuk dan jumlah mahar lebih sederhana dan murah dibandingkan dengan perkawinan antara Suku Sasak dengan yang lainnya. Pada empat perkawinan sesama Suku Sasak, dua yang terjadi di kecamatan Cakranegara, satu di kecamatan Ampenan, dan satu di kecamatan Sekarbela, hanya pada pasangan yang terakhir yang menggunakan mahar dalam bentuk emas selain seperangkat alat shalat yaitu perhiasan sebesar 7 gram. Sedangkan pada kedua tempat lainnya menggunakan seperangkat alat shalat dan uang sejumlah masing-masing Rp. 2 juta antara Lalu Hamidi Atmaja dan Baiq Sri Wahyuni (Cakranegara), 3 juta antara Muhammad Nasir dan Suliswati (Cakranegara) dan Rp. 5 juta atara Zainal Husni dan Hikmawati (Ampenan). Perbedaan jenis pembayaran yang menyertai seperangkat alat shalat ini bisa jadi karena di daerah Sekarbela merupakan tempat yang terkenal dengan toko-toko emas sehingga sedikit banyak mempengaruhi preferensi masyarakat untuk menggunakan emas juga.

Perbedaan jumlah uang yang diberikan untuk mahar sebagaimana pada data di atas juga dipengaruhi oleh beberapa faktor, tidak hanya karena keturunan tetapi juga latar belakang pendidikan. Contoh perkawinan Lalu Hamidi Atmaja dan Baiq Sri Wahyuni (Cakranegara), menentukan mahar berupa uang yang paling sedikit dibandingkan kedua perkawinana lainnya karena keluarga perempuan beralasan pihak laki-laki masih dibebani oleh berbagai macam pembayaran, yaitu pisuke dan pelengkak serta aji krama. Demikian pula perkawinan yang dilakukan oleh Zainal Husni dan Hikmawati (Ampenan) yang berlatarbelakang pendidikan Perguruan Tinggi dan program D3, menggunakan uang dalam jumlah yang lebih banyak dibandingkan dengan 
perkawinan yang dilakukan oleh Muhammad Nasir dan Suliswati (Cakranegara) yang keduanya sama-sama menyelesaikan pendidikan sampai sekolah menengah pertama saja.

Ketika perkawinan dilangsungkan antara laki-laki yang berasal dari Suku Jawa dan perempuan dari Suku Sasak, sama sekali tidak terjadi negosiasi dan permintaan yang berbentuk adat. Keluarga pengantin perempuan mengikuti saja bagaimana pengaturan dari keluarga pengantin laki-laki. Pernikahan yang berlangsung antara Wawan Kurniawan yang bekerja sebagai wartawan dan Weny Rahayu yang berkedudukan sebagai Pegawai Negeri Sipil dan samasama menamatkan pendidikan sarjananya tersebut tidak mensyaratkan pembayaran adat. Mahar yang dibayarkanpun hanya seperangkat pakaian shalat dan sejumlah seserahan pada saat datang melamar. Tetapi pesta yang dilakukan memang terbilang meriah dan menurut pengakuan mereka berdua, kedua mempelai dan dua belah pihak keluarga berkontribusi pada pesta yang di lakukan pada sebuah hall di Mataram itu.

Pernikahan yang dilakukan dengan laki-laki Suku Jawa, keluarga perempuan tidak menuntut karena masyarakat Sasak cenderung melihat orang yang berasal dari Suku Jawa lebih tinggi kedudukannya. Bahkan salah satu informan berseloroh bahwa: walaupun laki-laki dari Suku Jawa penjual cilok dan perempuannya mempunyai pekerjaan tetap dan terhormat, anggapan bahwa Suku Jawa lebih tinggi kedudukannya masih berlaku. Hal ini berbeda ketika menikah dengan suku yang lain, di mana keluarga perempuan Sasak bisa menuntut lebih banyak.

Asumsi tersebut di atas diperkuat oleh keterangan sesorang yang berasal dari Suku Jawa, Heru Susanto yang menikahi perempuan Suku Sasak dan bahkan berketurunan baiq (perempuan bangsawan). Menurut pengakuannya, saat dia menikahi istrinya sekitar dua puluh tahun lalu, ia masih menjadi mahasiswa semester akhir sebuah perguruan tinggi negeri di Mataram dan istrinya sudah menjadi perawat, tetapi ia tidak dimintai pembayaran adat. Cukup menyediakan mahar dan menyumbang biaya untuk begawe dan roah.

Lain halnya, misalnya, dengan pernikahan antara L. Mahbub dan Dewi Anggriani yang berasal dari Suku Sasak dan Suku Mbojo dan kedua-duanya berpendidikan perguruan tinggi. Pasangan ini memutuskan untuk lebih mengikuti adat Mbojo baik dengan cara melamar bukan dengan merariq dan metode pembayaran pernikahan. Karena di suku asal mereka, tidak ditemukan 
pembayaran adat yang beragam seperti di Sasak, maka negosiasinya terpusat pada satu jenis pembayaran adat yang disebut co'í. Co'i ini berbeda dengan pisuke karena lebih terkait dengan biaya pesta yang disebut dengan piti ka'a dan hadiah bagi pengantin perempuan. Tetapi mahar yang mereka sebutkan ketika ijab qabul berupa uang sejumlah Rp. 10 juta dan perhiasan emas lengkap seberat 27 gram. Sama halnya dengan pernikahan Saparuddin dan Siti Maimunah (Suku Sasak dan Suku Mbojo) yang bertempat di Kecamatan Ampenan. Mereka berdua hanya menampatkan pendidikan di tingkat dasar. Jumlah mahar yang disebutkanpun sederhana yaitu anting emas 3 gram.

Adapun pernikahan yang terjadi antara Muhammad Jalil dan Siti Rohani (Suku Sasak dan Suku Banjar) yang bertempat di Kecamatan Selaparang menggunakan pembayaran jujuran sebagai pembayaran adat di luar mahar. Hal ini karena berdasarkan negosiasi kedua keluarga, adat asal dari calon pengantin perempuan di pakai. Muhammad Jalil dan Siti Rohani yang samasama berpendidikan Perguruan Tinggi menghabiskan biaya yang relative banyak untuk acara pesta perkawinan karena mengundang banyak orang. Hal ini juga dipergunakan untuk menunjukkan status sosial serta ekonomi mereka karena mereka sudah sama-sama bekerja, yang laki-laki bekerja sebagai wiraswasta yang bergerak di bidang IT sedangkan yang perempuan adalah PNS yang berprofesi perawat. Oleh karena itu, pembiayaan pesta menyedot sebagian besar dana perkawinan ini sehingga disepakati, mahar hanya berupa sepasang anting emas dan cincin yang keseluruhan beratnya 7 gram ditambah dengan uang senilai 5 juta rupiah.

Tiga benang merah bisa diambil dari perkawinan sesama Suku Sasak dan (atau) dengan suku lain. Pertama, Suku Sasak memegang kuat tradisi dan adat terkait dengan upacara perkawinannya tetapi juga terbuka dengan modifikasi dan penyesuaian jika dihadapkan dengan adat budaya suku lain. Kedua, perkawinan antara suku bisa menjadi wahana untuk melihat negosiasi dinamis dan kesepemahanam budaya yang berbeda di antara keluarga. Dalam hal ini pembayaran untuk biaya pestalah yang lebih dikedepankan. Bahkan pada perkawinan sesama Suku Sasak juga dalam batas tertentu terjadi negosiasi dan kesepakatan dari perbedaan kecenderungan keluarga yang berbeda. Ketiga, kesamaan agama dengan latar belakang budaya yang berbeda menjadi benang merah bagi terselesaikannya perbedaan-perbedaan persepsi maupun praktek tentang pembayaran pernikahan. Pada titik ini agama, dalam hal ini 
mahar sebagai pembayaran yang berbasis agama antara pernikahan muslim ini menjadi something in common dalam semua perkawinan yang diobservasi oleh penulis.

Dalam fungsinya, pembayaran mahar menjadi titik pijak apakah pernikahan itu dianggap sah atau tidak walaupun pembayarannya bisa ditunda dan tidak harus ada pada saat akad ijab qabul. Menariknya pembayaran adat harus sudah ada sebelum ditentukan apakah pernikahan bisa dilangsungkan atau tidak. Tidak boleh dihutang dan harus tampak dan ditunjukkan setelah kesepakatan tentang jumlah dan pembayaran dicapai oleh kedua belah pihak.

Dengan merujuk pada teori pluralisme hukum yang dikemukakan oleh MB Hooker yang ia sebut dengan teori sinkretisme, ${ }^{15}$ pembayaran perkawinan Sasak memperlihatkan kekuatan yang seimbang atau koeksistensi dari agama, budaya dan negara bagi ikatan perkawinan. Lebih lanjut jika kategorisasi strong legal pluralism versus weak legal pluralism dipakai, maka ragam pembayaran budaya Sasak ini memperlihatkan saling terakomodasinya berbagai hukum yang ada, baik itu hukum agama, hukum adat, maupun hukum negara. Artinya yang sedang terjadi adalah pluralism hukum dalam bentuknya yang kuat di mana semua sistem hukum saling support tanpa saling menegasikan.

Topik pluralisme hukum telah didiskusikan sejak lama oleh para ahli, paling tidak sejak awal abad ke-20 M. Diskusi ini menjadi sangat penting dalam konteks Indonesia di mana banyak sistem hukum yang sama-sama berlaku. Di satu sisi negara memiliki sistem hukum yang lain dan karena kekuatannya, negara punya perangkat dan aparat untuk memaksakan hukum nasional berlaku bagi warganya. Di sisi lain, masyarakat yang oleh karena suku dan agarna memiliki dua sistem hukum yang berbeda yang juga ikut berkontestasi. Dalam hal ini hukum Islam bagi masyarakat yang beragama Islam dan hukum adat yang sudah disepakati pada kehidupan lokal masing-masing.

Menurut Hooker, aliran pluralisme hukum (legal pluralism) adalah sebuah situasi yang ditandai dengan keberadaaan secara bersama dua sistem hukum atau lebih yang saling berinteraksi dalam proses modernisasi hukum di sebuah negara. Legal pluralism dalam pandangan Hooker ini bersifat netral

15M. B. Hooker, Legal Pluralism: An Introduction to Colonial and Neo-Colonial Laws (Oxford: Clarendon Press, 1975). 
dalam arti tidak ada sistem hukum yang lebih unggul daripada yang lain.16 Tetapi jika menelusuri berbagai pendapat dan para ahli, sebenarnya legal pluralism itu ada yang dikategorikan lemah ada juga yang kuat.'17 Menilik pandangan Woodman' misalnya, ia melihat legal pluralism itu sebagai banyaknya sistem hukum tetapi ada satu sistem besar dalam hal ini hukum negara sedangkan yang lain hanyalah cabangnya. ${ }^{18}$ Tetapi dalam pandangan Moore ${ }^{19}$ legal pluralism itu hanya ditandai dengan parelelnya beberapa sistem hukum yang berbeda yang sama-sama ada dan berpengaruh tanpa dikooptasi oleh salah satu sistem hukum saja. Kalau yang pertarna bisa disebut sebagai weak legal pluralism sedangkan yang berikutnya bisa dikategorikan sebagai strong legal pluralism.

Dengan menggunakan perspektif pluralisme hukum, maka keragaman aturan dalam pembayaran perkawinan maupun pada aspek-aspek lain dalam masyarakat bisa dilihat sebagai aspek yang berkelindan tetapi juga terpisah dalam fungsi dan maknanya. Menurut penulis, perdebatan mengenai apakah praktek pembayaran perkawinan yang dilakukan Suku Sasak sesuai tidak dengan norma agama menjadi tidak relevan lagi.

\section{Kesimpulan}

Tradisi Sasak sangat terbuka bagi adaptasi dan penyesuaian dengan budaya lain. Hal ini terbukti ketika perkawinan dilakukan antara suku, maka biasanya pemuda Suku Sasak menyesuaikan dengan budaya di mana pengantin perempuan berasal. Bahkan ketika perkawinan seorang perempuan Suku Sasak dengan Suku Jawa, kesepahaman budaya maupun kondisi perorangan calon mempelai laki-laki menentukan bagaimana melakukan dan apa saja ragam pembayaran pernikahan tersebut. Dengan demikian negosiasi dan kesepahaman budaya ini juga memperlebar pengertian tentang pluralisme

\footnotetext{
16Hooker.

${ }^{17} \mathrm{~A}$. Salim, "Contemporary Islamic Law in Indonesia: Sharia and Legal Pluralism," dalam Exploring Muslim Contexts, ed. Farouk Topan, vol. 6 (Edinburgh: Edinburgh University Press Ltd., 2015), 24.

${ }^{18} \mathrm{~A}$ G. Woodman, "The Idea of Legal Pluralism," dalam Legal Pluralism in the Arab World (Arab \& Islamic Laws), ed. Baudouin Dupret, Maurits Berger, and Laila Al-Zwaini (The Hague: Kluwer Law International, 1999), 3-20.

${ }^{19}$ Sally Falk Moore, Law as Process: An Anthropological Approach (London: Routledge \& Kegan Paul, 1983).
} 
hukum bahwa co-exsistence dan dialog tidak hanya terjadi antara sistem hukum Islam, adat, dan negara tetapi juga intern hukum adat dalam arti pada tradisi yang berbeda antara etnis.[a]

\section{DAFTAR PUSTAKA}

Aini, Noryamin. "Tradisi Mahar di Ranah Lokalitas Umat Islam: Mahar dan Struktur Sosial di Masyarakat Muslim Indonesia." Ahkam: Jurnal IImu Syariah 14, no. 1 (2014). https://doi.org/10.15408/ajis.v17i1.1239.

Bartholomew, Jhon Ryan. Alif Lam Mim: Kearifan Masyarakat Sasak. Yogyakarta: Tiara Wacana, 2001.

Budiwanti, Erni. Islam Sasak: Wetu Telu versus Waktu Lima. Yogyakarta: LKiS, 2000.

Hazairin. Tujuh Serangkai tentang Hukum. Jakarta: Tinta Mas, 1974.

Hidayat, Fatah. "Dinamika Perkembangan Hukum Keluarga di Indonesia." An Nisa'a 9, no. 2 (2014): 1-22. http://jurnal.radenfatah.ac.id/index.php/ annisa/article/view/265.

Hooker, M. B. Islamic Law in South-East Asia. Singapore: Oxford University Press, 1984.

- - Legal Pluralism: An Introduction to Colonial and Neo-Colonial Laws. Oxford: Clarendon Press, 1975.

Ja'far, Ahmad Khumaidi. "Teori-Teori Pemberlakuan Hukum Islam di Indonesia." ASAS 4, no. 2 (2012): 102-10. http://ejournal.radenintan. ac.id/index.php/asas/article/view/1679.

Moore, Sally Falk. Law as Process: An Anthropological Approach. London: Routledge \& Kegan Paul, 1983.

Rahayu, Sri, dan Yudi Yudi. "Uang Nai': Antara Cinta dan Gengsi." Jurnal Akuntansi Multiparadigma 6, no. 2 (2015): 224-36. https://doi.org/ 10.18202/jamal.2015.08.6018.

Ar-Razak, Aris Nur Qadar. "Praktek Mahar dalam Perkawinan Adat Muna (Studi Kabupaten Muna, Sulawesi Tenggara)." Tesis, Universitas Islam Negeri Sunan Kalijaga, 2015.

Salim, A. "Contemporary Islamic Law in Indonesia: Sharia and Legal Pluralism." Dalam Exploring Muslim Contexts, ed. Farouk Topan, Vol. 6. Edinburgh: Edinburgh University Press Ltd., 2015. 
Saputra, Hirmayadi. "Hukum Adat dan Hukum Islam dalam Tradisi Penentuan Mahar di Kecamatan Pujut Kabupaten Lombok Tengah." Tafaqquh: Jurnal Hukum Ekonomi Syariah dan Ahwal Syahsiyah 1, no. 2 (2016): 76-86. http://ejournal.kopertais4.or.id/sasambo/index.php/tafaqquh/article/ view/3048.

Sejarah Kota Mataram, Pemerintah Kota Mataram - Mataramkota.go.id.

Suryani, E. "Merarik dalam Bingkai Kearifan Masyarakat Lombok." dalam Jejak Jender, ed. Atun Wardatun. Mataram: PSW IAIN Mataram, 2010.

Thalib, Sayuti. Receptio A Contrario. Jakarta: Bina Aksara, 1980.

Vandita, Lalu Yoga. "Praktek Tradisi Gantiran dalam Perkawinan Persfektif Hukum Islam." Tafaqquh: Jurnal Hukum Ekonomi Syariah dan Ahwal Syahsiyah 1, no. 1 (2016): 58-72. http://ejournal.kopertais4.or.id sasambo/index.php/tafaqquh/article/view/3038.

Wardatun, Atun. "Marriage Payment, Social Change, and Women 's Agency among Bimanese Muslims of Eastern Indonesia." Tesis, Western Sydney University, 2016.

Woodman, A G. "The Idea of Legal Pluralism." Dalam Legal Pluralism in the Arab World (Arab \& Islamic Laws), ed. Baudouin Dupret, Maurits Berger, dan Laila Al-Zwaini. The Hague: Kluwer Law International, 1999.

Yaswiraman. Hukum Keluarga: Karakteristik dan Prospek Doktrin Islam dan Adat dalam Masyarakat Matrilineal Minangkabau. Jakarta: Raja Grafindo Persada, 2013.

Zuhdi, Muhammad Harfin. "Praktik Merariq: Wajah Sosial Masyarakat Sasak.” Laporan penelitian, Lembaga Pengkajian-Publikasi Islam dan Masyarakat (LEPPIM) - IAIN Mataram, 2012. 